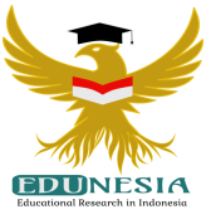

\title{
Policy Formulation and Adoption of Revised Islamic Education Curriculum as stated in the Decree of Religion's Ministry (KMA) Number 183 of 2019
}

\author{
Omay Komarudin'1; Qiqi Yulianti Zakiyah²; Supiana ${ }^{3}$ \\ 1,2,3 Management of Islamic Education, UIN Sunan Gunung Djati Bandung, Indonesia \\ 1Corresponding Email: omaykomarudin79@gmail.com, Phone Number: 0821 xxxx xxxx
}

\author{
Article History: \\ Received: Mar 15, 2021 \\ Revised: May 05, 2021 \\ Accepted: May 09, 2021 \\ Online First: May 11, 2021
}

\section{Keywords:}

Islamic Education, Formulation, Legitimation.

Kata Kunci:

Formulasi, Legitimasi, Pendidikan Agama Islam.

\footnotetext{
How to cite:

Komarudin, O., Zakiyah, Q.Y., \& Supiana, S. (2021). Policy Formulation and Adoption of Revised Islamic Education Curriculum as stated in the Decree of Religion's Ministry (KMA) Number 183 of 2019. Edunesia: Jurnal Ilmiah Pendidikan, 2 (2): 514-526.
}

This is an open access article under the $\mathrm{CC}-\mathrm{BY}-\mathrm{NC}-\mathrm{ND}$ license

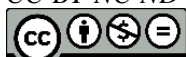

\begin{abstract}
The stages in making the education policy process by Formulation and Adoption process. The policy formulation is intended for the best problem solving derived from various alternatives or existing policy options. The problem of revision of the Islamic Education curriculum is one of the solutions for handling radicalism in Islamic Religion Education (IRE) curriculum from several policy options including the elimination of jihad and caliphate material, changing subjects, transferring caliphate material to subjects of Islamic cultural history, while Jihad material is more directed towards a seriousness to do best activities. After choosing the best policy, it needs to be legitimized so that the decision is well received because it is in accordance with the procedures applicable to the general public and political or moral values. The policy for revising the IRE curriculum is contained in Decision of Religion Ministry no 183/2019 and endorsed by the Ministry of Religion in the field of Islamic Education, so that it becomes the best guideline in national and state life by maintaining national security stability.
\end{abstract}

Abstrak: Tahapan dalam pembuatan proses kebijakan pendidikan adalah formulasi dan adopsi. Formulasi kebijakan dimaksudkan untuk pemecahan masalah yang terbaik yang berasal dari berbagai alternatif atau pilihan kebijakan yang ada. Permasalahan revisi kurikulum Pendidikan Agama Islam (PAI) /Islamic Religion Education (IRE) merupakan salah satu solusi penanganan radikalisme dalam kurikulum PAI dari beberapa pilihan kebijakan diantaranya penghapusan materi jihad dan khilafah, penggantian mata pelajaran, pengalihan materi khilafah ke mata pelajaran sejarah kebudayaan Islam, sedangkan materi Jihad lebih diarahkan kepada kesungguhan untuk beramal. Setelah dipilih kebijakan yang terbaik, selanjutnya perlu dilegitimasikan supaya keputusan tersebut diterima dengan baik karena telah sesuai berdasarkan prosedur yang berlaku pada masyarakat umum dan nilai-nilai politik atau moral. Kebijakan revisi kurikulum Pendidikan Agama Islam tertuang dalam peraturan Keputusan Menteri Agama (KMA) no 183 tahun 2019 dan diabsahkan oleh Kementerian Agama bidang Pendidikan Islam, supaya menjadi pedoman terbaik dalam kehidupan berbangsa dan bernegara dengan menjaga stabilitas keamanan nasional. 


\section{A. Introduction}

After incident of attacking terrorist in September 11, the President of George Bush announce new catchword of war against terrorism (Arif et al, 2017). He called for global participation against terrorism and declared that the September 11 terrorist attacks as 'the war of the first war of the twenty-first century'. Radicalism has become a threat in the diversity of nation and state, this is caused by a lack of tolerance toward diversity that has become a natural tendency. This radicalism originated from an understanding about religion, which gave rise to a fanatical attitude which assumed that their religion is the only true religion in the word (Rohman \& Nurhasanah, 2019).

Actually, Terrorism is a product of the radicalization process, the massive effects of radicalization ideology have resulted in an increase in the threat of terrorism in all over the world (Tahaj \& Logahan, 2019). In Indonesia, both since the era of independence, the old order, the new order and even the era of reform, radicalism has developed rapidly with different forms. The escalation of bombing appeared more massive in the post-reform era because the efficiency of freedom was everywhere and the government was not too strict in controlling NGOs (non-governmental organizations) and other social organizations. Quoted from Endi (2010), starting from the 1999 Ramayana Jakarta Department Store Bombing, the Kelapa Gading Mall Bombing, the Hayam Wuruk Plaza Bombing followed by the 2000 Bombing at the Philippine Embassy Bombing (1 August 2000), the Malaysian Embassy Bombing (27 August 2000), The Bursa Effek Bomb (September 13, 2000), and the Christmas Eve bombing (December 24, 2000), in the following year, the bombings were more numerous and the explosions were bigger.

The increase in the threat of terrorism in Indonesia can be seen from the large number of victims who fell, namely as many as 35 police died and 67 police were injured in an effort to fight terrorism in the 2014 to 2015. From a total of 171 terrorism acts that have been successfully revealed. During 2000 to 2015, there were 1,064 suspected terrorists who had been arrested (Tahaj \& Logahan, 2019). Even in all over the world, According to the global terrorism database1, terrorist groups killed roughly 43,412 people in 2014, rising from 22,211 in 2013 and 3,329 in 2000 (http:/ / www.start.umd.edu/gtd/).

Usually terrorists have certain targets to launch their attacks, namely government centers, offices, malls, embassies, airports, places of worship, and public places such as schools, markets, tourist attractions and other places. Bradford and Wilson (2013) suggest that children and educational institutions may be particularly vulnerable to terrorism because they are "soft targets" - typically unguarded sites of congregation that provide an opportunity for mass casualties. The 213 attacks reported between 2005 and 2009 rival the 170 that took place during the preceding 35 years. Again, this analysis does not intend to conflate reports with actual incidence, but the the most recent period alone, between 2010 to 2014, the number of terrorist incidents involving child-serving schools has already surpassed the previous 5 years, threefold (START, 2016).

Salafi Jihadi has been widely accused of being the actor behind terrorist acts in various parts of the world (Syauqillah \& Faton, 2019). In Indonesia, acts of terror are generally carried out by parties who have relations with the Salafi movement who have transmissions at the regional and global levels. The Salafi movement literature originating from the middle east, accompanied by political dynamics and conflict in the middle east, has become the light of the radical movement in Indonesia. Along with changes in the social and political order, especially after the arrival of young Arabs from Hadramaut Yemen to Indonesia who brought a new ideology to their homeland, helped change the constellation 
of muslims in Indonesia (Asrori, 2019). They carry a stricter and intolerant ideology, this is influenced by the Maliki school that was adopted and introduced by Muhammad bin Abdul Wahab or Wahabi, which is currently the official ideology of the Saudi Arabian government.

Medeline Albright, Secretary of AS' county, said that from thirty of the world's most dangerous terrorist organizations, more than half of them are religious groups (Edyar, 2017). They have religion such Islam, Jew, Christian, Buddist etc but sometimes they have different with other socities, they have special group and special doctrine that they are only them themsef which is right, others are wrong and even must be killed.

Every religion has content or material that is taught usually in School, In Islam, the place for studying content of religion is called Madrasah. But unfortunately After the September 11, 2001 terrorist attacks, as there was a growing perception that terrorism in the Middle East, Central, and Southeast Asia region is fueled by these madrasah. These traditional schools were alleged to seed the religious extremism among their students. Islamic religion and its teaching were misunderstood as a religion which propagates its followers to regard non-Muslim as enemy and a threat to the Islamic religion (Khan, 2005). The misconception of Islamic teaching, such as the concept of jihad, religious freedom and minority rights under Islamic law, has been identified as the main reasons that contribute to a clash between the Islamic civilization and the modern world order (Ahmed 2007). In Indonesia, for example, there is allegation that the terrorism activities are headed by certain Muslim clerics, such as Abu Bakar Bashir, who are also the founders and teachers of the traditional religious schools (Arif et al, 2017).

Edyar (2017) in his article quoted Ahmad Syafi'i Mufid that Terroris groups can be identified in Indonesia by: a) assuming that Indonesian government as thogut, B) rejecting Indonesia Raya's song and respect the flag, C) having strong emotional bonding rather than emotional bonding to family, college and work, D) recitation and caderisation are done in private, E) pay the ransom for sin, F) dressed as typical in cinkrang and bearded also veiled for women, G) Muslims outside their group are considered ungodly and pagan before they hijrah, and H) reluctant to hear lectures of people outside their group.

With the proliferation of massive radicalism, the solution approach for each government is different. There is a persuasive approach as well as a military approach to avoiding the impact of even greater damage. In the last 6 years, the approach to handling radicalism has been more comprehensive and more massive, not only with military, social, cyber control (social media) approaches but also entering the areas of education, recitation, Islamic boarding schools and even the Islamic religious curriculum.

In the legal aspect, there are also improvements to binding and entangling regulations so that they can control Islamic organization that can endanger the security of the state. The government made Law number 2 of 2017 as a substitute for government regulations. The content of the regulations is to revise the regulations if there are mass organizations that endanger national security and defense. As a follow-up to this Law, through the Director General of General Legal Administration of the Ministry of Law and Human Rights, Freddy Harris, to be precise On 19 July 2017 Hizbut Tahrir Indonesia was officially dissolved by the government (Ahmadi \& Prasetyo, 2005). Although Hizbut Tahrir Indonesia HTI has shown its existence in Indonesia for approximately 40 years, and has spread to all provinces in Indonesia. The next step, the government is even firmer in fighting terrorism and radicalism, namely with Ulama certification, which means that scholars are given a certificate of eligibility for lectures for their competence, monitoring recitation and Friday sermons in mosques, calling for improvements to the pesantren curriculum to be free 
from radical teachings and prohibiting civil servants from wearing trousers. veiled and veiled.

It is not enough that all exam materials at madrassas some time ago that contain content from the caliphate and war or jihad have been ordered to be withdrawn and replaced. This is adjusted to the provisions of the assessment regulations stipulated in the Decree of the Director General of Islamic Education Number 3751, Number 5162 and Number 5161 of 2018 concerning Guidelines for Assessment of Learning Outcomes at MA, MTs, and MI. (Republika.co.id, Saturday, 07 Dec 2019). The reason is that currently there is a need for moderation in religion, especially Islam as a manifestation of the Decree of the Director General of Islamic Education. Then the elimination of the terms khilafah and jihad was emphasized in the Circular Letter B-4339.4 / DJ.I / Dt.I.I / PP.00 / 12/2019 on December 4, 2019.

In the Jabar Express online newspaper on Wednesday, November 13, 2019, the Ministry of Religion remodeled 155 titles of Islamic religious textbooks about the caliphate so that it reaped the pros and cons. Overhaul will be carried out all religious textbooks starting from grade 1 elementary school to grade 12 high school. This is intended to prevent radicalism. The Ministry of Religion then instructed to withdraw all subjects containing the content of the caliphate and jihad.

This decision by the Ministry of Religion was rejected by the deputy chairman of Commission VIII House of Representatives (DPR) from the Golkar faction, Ace Hasan Syadzily. The Minister of Religion (Fachrul Razi) does not need to remove teaching content about the caliphate and jihad in Islamic religious lessons at madrassas (CNNIndonesia.com, Monday (9/12). radical understandings, the method is not a complete elimination of material, because if this is done, according to him, it will cover up the history that has occurred in Islamic civilization.

This situation has received the spotlight for Islamic activists, especially in the development of civil disunity in the 2019 tajhun which still has scars after the political events of the Presidential and Pilkada elections and other issues that continue to rage incessantly. With the revision of the IRE curriculum by eliminating the content of Jihad and the Khilafah, it made conditions uncomfortable for Muslims. So that it adds to the belief that the government is as if the Muslim Ummah is being cornered and is the source and nest of terrorists.

The change/revision of the Islamic Education curriculum is contained in the Decree of the Minister of Religion (KMA) No. 183 of 2019 concerning Guidelines for Islamic Education Curriculum and Arabic in Madrasas and KMA No.184 of 2019 concerning Guidelines for Implementing Curriculum in Madrasas. Is it true that in the name of the deradicalization project, a policy of ulama certification, supervision of mosques and majelis taklim was adopted, and now there are changes to the curriculum regarding caliphate and jihad materials?

This study does not specifically address the problem of radicalism, but analyzes the formulation and adoption of the IRE curriculum revision policy making. What are the considerations, how urgent the problem is and who is the decision making and what are the preferences? and how is the legalization of the Islamic Education curriculum revision for Indonesian citizens, especially education people?

As an inspiration and comparison with the study of this title, several journals related to this theme were taken, namely as follows: 
1. Radicalism in Indonesia: between historisity and anthropicity by (Asrori, 2019) which explains the grassroots of radicalism, history and how to deal with terrorist actors in both military and military forms.

2. Dissolution of Hizbut Tahrir in Indonesia in a socio-political perspective by Prasetyo (2019) explains that HTI is formally juridical and has been dissolved but according to the socio-political aspect, ideology will continue to be unstoppable, but HTI in Indonesia does not carry out violence in its preaching. Although the movement is against the ideology of Pancasila.

3. Formulation of government policies regarding the establishment of regional owned enterprises (Bumd), limited liability companies (Pt), mass rapid transit (Mrt) Jakarta in DKI Jakarta Province by Bintari and Pandiangan (2016) from the Department Governmental Science, Faculty of Social and Political Sciences, Padjadjaran University. There are 4 stages of formulation carried out so as to produce a policy for the formation of BUMD PT MRT Jakarta, namely formulation of problems, agenda setting, selection of alternative policies to solve problems and the stage of determining policies. Slow decision-making regarding the construction of the MRT has influenced the formation of PT MRT Jakarta.

4. Formulation of free education policy for Pelalawan district in 2013 by (Anwar and Darwis, 2015) from the Governmental Science Study Program, Faculty of Social and Political Sciences, Riau University. He analyzed these problems using Jeffrey. Frieden's (2000) frame of mind: first, formulating or identifying actors and their goals, second determining actor policy preferences, third determining how they group themselves, and fourth following their interactions with other social institutions.

5. Concepts and theory studies of public policy formulation by (Muadi et al, 2016), experts from various universities stated that there are many models of public policy formulation with various advantages and disadvantages.

In this study, it remains focused on how the process of formulating and adopting the Islamic Education curriculum revision policy number 183 in 2019.

\section{B. Method}

To discuss this study, a descriptive qualitative method is used which means analyzing the problem and then describing the problem clearly from a library research with metaphysical realism as the approach (Muhadjir, 1996). The data sources of this research are journals, newspapers, and literature books related to policy decision making, both in the context of education and in the context of government. The background to the majority of problems is obtained from online newspaper sources, government regulations as well as from journals related to radicalism, jihad and the caliphate. Then the problem uses qualitative data analysis simultaneously, namely categorization, data reduction, data presentation, and drawing conclusions or verification (Miles and Huberman, 1992). 


\section{Result and Discussion}

In taking a policy such as the Islamic education curriculum revision policy, the stages must be passed first. Winarno (2012) suggests an agenda for the stages of public policy, namely:

\section{Agenda Development}

Agenda setting is a very strategic phase and process in the reality of public policy. The formulation of the policy agenda must be done based on the urgency and essence of the policy, as well as the involvement of stakeholders. Some that are set into the agenda must consider the agenda: 1). has reached a certain critical point if ignored, will become a serious threat; 2). having reached a certain level of particularity will have a dramatic impact; 3 ). concerning certain emotions from the point of view of the public interest (mankind) and receiving mass media support; 4 ). reach a very broad impact; 5). questioning power and legitimacy in society; 6). Concerning a fasionable issue (difficult to explain, but easy to feel its presence). Those are the criteria for issues that can be used as a public policy agenda (Kimber, 1974; Salesbury 1976; Sandbach, 1980; Hogwood and Gunn, 1986).

Judging from the criteria for issues raised by Kimber in nos. 1 and 2, it can be ascertained that the revision of the IRE curriculum is very urgent because if it is ignored it will become a serious threat to the stability of state security due to the birth of massive numbers of new, highly educated terrorists.

\section{Policy formulation}

Issues that are already on the policy agenda are then discussed by policy makers. These problems are defined so that the best solution to the problem is sought. The solution to the problem comes from various alternatives or existing policy options.

The problem of Islamic education curriculum revision is one of the solutions for handling radicalism in the IRE curriculum. In the content of the IRE curriculum, there are jihad and caliphate material, if the material is used by irresponsible people, it is possible to become an easy ground for teachers to indoctrinate students with the provision of jihadist verses that are interpreted to disbelieve other people, legalize their blood and may be allowed to rebel against a government that is legitimate. In addition, it is possible that the doctrine of the caliphate and the doctrine of jihad is instilled in hatred against the state which is then eager to establish a state by unifying with other countries into one unit (trans national).

But also the material of jihad and caliphate is the material that actually exists in Islamic teachings, if then this material is removed completely it will cause great upheaval. And in turn the Ummah is completely ignorant of the concept of Islam as a whole which includes all aspects of life including the fields of struggle in terms of politics, social economy and culture.

Some alternative choices of curriculum content regarding jihad and caliphate are that the material is completely eliminated and these subjects still exist, change the overall content of the IRE curriculum to replace it with a completely new one, or still exist but with a nonradical interpretation. This alternative should be considered with various risks. If there is a risk, the effect of that risk is not too big.

Unfortunately, before issuing a policy, the officials issued a statement that there would be a withdrawal of 155 books to be revised containing jihad and caliphate content, it 
is clear that the Ummat at that time was already tired of the post-presidential and regional election conflicts, the issue became heated and drew various criticisms and spotlight sharp.

The issue heated up when there was an official circular letter for the elimination of the terms khilafah and jihad written in Circular Letter B-4339.4 / DJ.I / Dt.II / PP.00 / 12/2019 on December 4, 2019 regarding instructions for withdrawing all subjects containing content caliphate and jihad. Because it was viral and received very sharp criticism, the Ministry of Religion then provided an explanation that there was no deletion of the material but rather a diversion. The subject of the caliphate was originally in the subject of Jurisprudence and shifted to the Islamic Cultural History $(\mathrm{ICH})$ with the aim of providing insight into the diversity of government systems. These changes are contained in the Decree of the Minister of Religion (KMA) No. 183 of 2019 concerning Guidelines for Islamic education curriculum and Arabic in Madrasas and KMA No.184 of 2019 concerning guidelines for implementing curriculum in Madrasas.

With the issuance of KMA letter No. 183, it becomes the best way to determine policies in accordance with the theory. Policy formulation states that the risks taken are not too big get the spotlight of the contra society. The Ministry of Religion transferred the concept of khilafah to historical subjects to prove that there is a historical perspective khilafah, although certain circles were not satisfied because it was previously in the scope of the subject of Fiqh which means that syari'at/teachings must be carried out. Meanwhile, the term Jihad is limited to only telling the persistence of the Prophet and his companions who tried hard to worship and find a living in the world for their worship. But for some circles there were protests because it obscured the real situation about Jihad. The Ministry of Religion takes a middle path, Jihad still exists only in the level of not conflict, violence but at the level of being serious about seeking knowledge and giving charity.

The curriculum revision policy formulation can also consider some of the opinions of experts, namely the incremental theory, which states that public policy is a variation or continuation of past policies so that it is necessary to maintain the good performance that has been achieved, this theory has a pragmatic nature (Tilaar \& Nugroho, 2008). In terms of the content of the IRE curriculum, most of them are quite good by adjusting the concept of the 2013 curriculum, although there are many things that need to be improved. So Islamic education subjects in madrasah should not be removed but those that are considered less relevant to the situation should be reviewed.

The second analysis knife is to consider the formulation of the Islamic education curriculum revision policy using democratic theory, this theory mandates that the government in making policies, its constituents, and beneficiaries be accommodated. In short, all the stakeholders involved from Islamic organizations, Muslim activists who are pro and contra, representatives of teachers and supervisors, curriculum experts and national defense experts sit together to reach an agreement on the solution to the problem of IRE curriculum content which is considered to endanger the stability of state security. If the theory is carried out properly with sincerity and mutual interest, each party has an obligation to participate in achieving policy success because each party is responsible for the formulated policy.

The third analysis that becomes a consideration for curriculum revision is to use strategic theory, namely strategic planning which requires extensive collection of information, exploratory alternatives and emphasizes future implications with current decisions. This study involves only a few experts in identifying and solving issues, as well as assessing the impact on the environment outside and within the organization and is 
action-oriented. Strategic planning is intended to think strategically and develop effective strategies, clarify future directions, create priorities, make decisions now with regard to future consequences.

The theory above mostly explains how considerations are in making policy formulations. It is also good for us to analyze from the perspective of observation as someone outside the policy maker to see objectively and in detail about who, what and what purpose the policy formulation was made. Frieden (2000) proposes four thinking frameworks to see the formulation of policy, namely: first, to formulate or identify actors and their goals, second to determine actor policy preferences, third to determine how they group themselves, fourth to follow their interactions with other social institutions.

\section{Involved Actors}

The Islamic Education curriculum revision policy ensures that there are parties involved in it both in the initial formation of regulations, the process of forming regulations, up to the enactment of these regulations. These actors are assumed to be Muslim religious experts, consultants, curriculum developers, bureaucrats, lawyers and others.

These actors must act ideally as what the ummat voices, but the unity and integrity of the nation must also be considered, lest conflict escalate and radical seeds grow massively in formal and state institutions. students. Even if there is the concept of jihad and caliphate, it must be taught in universities so that students can respond wisely. These actors act and think to maximize the benefit, safety, comfort and and make the best calculation of profits and losses.

\section{Actor Preference in Formulating Policy}

All citizens, regardless of religion, ethnicity and color, want peace and a comfortable life without violence and coercion from anyone. Likewise, the actors who formulated the revised formulation of the IRE curriculum have the aim that the life of the nation and the state is not torn apart, does not suspect each other, lives in harmony in the state container Pancasila with multicural principles.

In addition, the Ministry of Religion as a representation of the state and government is obliged to attend and carry out the state's function as a fortress of defense and security, as a function of regulation and justice, as a function of prosperity and welfare. The latter function will not be realized if the state is in instability.

\section{The Social Basis of Policy Actors}

In making the process of formulating the Islamic Education curriculum revision policy, the actors of this policy should look at their educational background, mass organizations, track record, ethnicity and even culture. Even though it consists of various different understandings, due to differences in backgrounds, mass organizations and cultures, the actors who make this policy formulation have the same goal, namely to create IRE curriculum content that does not make noise and become a big problem in the future. Because students now are the successors of future leadership. 


\section{Resources owned by actors}

The mechanism for the formulation of the Islamic education curriculum revision policy involved several actors, both from the Ministry of Religion bureaucrats, scholars from universities, Islamic activities and representatives of Islamic organization who interacted with each other in drafting the decision even from different backgrounds. The parties involved in the formulation of this policy understand the risks and what are the benefits for the survival of citizens both in the short term and in the long term.

In terms of the process of formulating the Islamic education curriculum revision policy, the actors, both from scholars, bureaucrats, representatives of mass organizations, and Islamic activists have their respective resources. Scholars are elements of higher education, bureaucrats are elements of the Ministry of Religion, representatives of Islamic organization are representatives of the majority of the people, and Islamic activists are representations of vocal voices that emerge from the community. Actors are all the best resource accusers who can make wise decisions.

Apart from these actors, the National Agency for the prevention of terrorism is also involved in its duties according to presidential regulation of the republic of indonesia number 46 year 2010 which formulates policies, strategies and national programs in the field of counterterrorism covering preventive measures, protection, deradicalization, action and national preparedness.

After reaping harsh criticism and going viral in the mass media, regarding the review of 155 books, eliminating the terms jihad and khilafah, and objections from House of Representatives (DPR) members through hearings with the Ministry of Religion. Then there was a change in policy, namely there was no elimination of material but the transfer of material from the caliphate which was originally in the subject of Jurisprudence to the Islamic Cultural History ( $\mathrm{ICH}$ ) directed as an insight into the diversity of government systems. These changes are contained in the Decree of the Minister of Religion (KMA) No. 183 of 2019 concerning Guidelines for Islamic Education Curriculum and Arabic in Madrasas and KMA No.184 of 2019 concerning Guidelines for Implementing Curriculum in Madrasas. This new curriculum will be used starting from the 2020/2021 Academic Year.

The Acting Director General of Islamic education at the Ministry of Religion, Kamaruddin Amin (https://www.medcom.id/pend Pendidikan/) revealed that the KMA did not completely change the contents of the previous curriculum contained in KMA 165/2014. perfecting several Core Competencies (KI) and Basic Competencies (KD), "he said in Jakarta, Monday (13/7/2020).

There are three equations for the two KMAs. First, the equality of subjects. The madrasah curriculum consists of Quran Hadith, Akidah Akhlak, Jurisprudence, Islamic Cultural History ( $\mathrm{ICH}$ ) and Arabic. The second equation, said Kamaruddin, is still using the principles of learning in the 2013 National Curriculum. The third equation uses the principles of assessment that apply to the enhanced 2013 National Curriculum.

The refinement of this curriculum is based on the results of research on Religious and Religious Education at the Ministry of Religion Research and Development Center (Puslitbang) which found that there are several overlapping material structures between levels and between classes. This study also assesses that the formulation of competency levels is still too low. Another finding is that Arabic material is considered to be structuralist.

Based on these weaknesses, the curriculum in madrasas must meet the needs of 21st century education development, the need for character building for the Indonesian nation as a global citizen, and the achievement of the vision of a Sovereign, Advanced, Just and 
Prosperous Indonesia. In detail, there are eight focuses on improving the IRE curriculum revision, namely:

a. Reorganizing the distribution of materials that overlap between levels and between classes.

b. The formulation of improved competency levels to equip higher level students in critical and innovative thinking. So that the MI competency level is increased by almost 30 percent of KD with level C4, MTs 70 percent and MA 90 percent at levels C4 to C6.

c. Arrangement of continuity and harmony of formulation between KD 1 Spiritual Attitude, KD 2 Social Attitudes, KD 3 Knowledge and KD 4 Skills.

d. Strengthening Islamic education and Arabic subjects in the aspects of religious attitudes and skills rather than knowledge or cognitive.

e. Strengthening Islamic education subjects and Arabic to generate students' confidence and appreciation in proving that Islam is a religion that is very relevant to the progress of contemporary life.

f. Strengthening Islamic education subjects and Arabic as an introduction for students to become Indonesian citizens who live in diversity.

g. Changes in Arabic language material, especially improvements in the presentation and approach methods used so that it emphasizes more on a functional rather than a structural approach.

h. Improving the depth of curriculum material for Islamic education subjects at Madrasah Aliyah (MA) with special interest in Religion, as well as the use of Arabic language in teaching IRE and Arabic in the MA Religious Program.

\section{Policy Adoption / Legitimacy}

The purpose of policy legitimacy is to authorize the basic processes of government. According to Silalahi in Ali Imron (Wisdom of Education in Indonesia, 2002), Legitimacy comes from the word legitimation which means: a specific process in which government programs are authorized or endorsed. Legitimacy can also mean the principle that shows the acceptance of decisions of government leaders and officials by (most) the public on the basis that the acquisition of leaders and the exercise of power is in accordance with procedures that apply to the general public and political or moral values.

In the context of the policy of revising the Islamic Religious Education curriculum, the most appropriate legitimate measure is by the Ministry of Religion in the field of Islamic Education, citizens should follow the directions and government regulations that have been established in accordance with official procedures based on the principle of deliberation.

Legalized policy formats are usually recorded and written down for guidance by interested parties. The form of this education policy is usually in the form of education laws, instructions, government regulations, court decisions, ministerial regulations, and so on regarding education. The format of the IRE curriculum revision policy is contained in KMA regulation no 183/2020.

The policy of KMA regulation No. 183 must first be legitimized. This is understandable because the results of these policy formulations need to be recognized by the public. And, the recognition is made by the general public through community representative institutions. The issue of the IRE curriculum revision policy was born after a 
hearing of members of the House of Representatives (DPR) who rejected the elimination of jihad and caliphate material, then the Ministry of Religion improved the content of the IRE curriculum so that the birth of KMA No. -Critical notes at the hearing. So it can be seen that the policy has received recognition from the public because House of Representatives (DPR) members approved it. The more people who participate actively in its implementation, the more successful this policy is.

The form of public recognition of wisdom, among others, is through endorsement. Validation is a process in which the formulated educational policies are validated. Thus, after the formulation of the policy has received recognition from the public, the policy can be interpreted as valid, in other words the policy is declared to be enforceable.

Despite reaping the pros and cons and taking a tortuous journey, the Islamic Education curriculum revision policy can fulfill the principles of policy theory on the benefits of legitimacy, including:

1. Creating political stability and social change.

2. Troubleshoot faster.

3. Reducing the use of targets for physical violence.

4. Expanding the field of welfare or improving the quality of welfare.

\section{Conclusion}

From the above explanation, the conclusions of the policy formulation for the revision of the Islamic Religious Education curriculum are as follows, namely:

a. The pros and cons of eliminating the content of the caliphate and jihad in the Islamic Religious Education books and curriculum have been viral in the mass media, so members of the DPR (People's Representative Council) have asked for improvement.

b. Incremental policy formulation theory states that public policy should maintain the good performance that has been achieved, this theory has a pragmatic nature (Tilaar and Nugroho, 2012). In terms of the content of the IRE curriculum, most of them are quite good by adjusting the concept of the 2013 curriculum, although there are many things that need to be improved. So Islamic Education subjects in madrasah should not be removed but those that are considered less relevant to the situation should be reviewed. The democratic theory mandates that the government in making policies accommodates its constituents and policy beneficiaries. In short, all the stakeholders involved from Islamic organizations, Muslim activists who are pro and contra, representatives of teachers and supervisors, curriculum experts and national defense experts sit together to reach an agreement on the solution to the problem of IRE curriculum content which is considered to endanger the stability of state security. If the theory is carried out properly with sincerity and mutual interest, each party has an obligation to participate in achieving policy success because each party is responsible for the formulated policy. Strategic theory emphasizes strategic planning by requiring extensive collection of information, exploratory alternatives and emphasizes the implications of the future with current decisions. Strategic planning is intended to think strategically and develop effective strategies, clarify future directions, create priorities, make decisions now with regard to future consequences.

c. Legitimacy means the principle that shows acceptance of decisions by government 
leaders and officials by (most) the public on the basis that the acquisition of leaders and the exercise of power is in accordance with the procedures applicable to the general public and political or moral values. In the context of the policy of revising the Islamic Religious Education curriculum, the most appropriate legitimate measure is by the Ministry of Religion in the field of Islamic Education, citizens should follow the directions and government regulations that have been established in accordance with official procedures based on the principle of deliberation.

\section{References}

Ahmadi, A., \& Prasetyo, J. (2005). Strategi Belajar Mengajar. Pustaka Setia.

Ahmed, P. (2007). Terror in the Name of Islam - Unholy War, Not Jihad, Case Western Reserve Journal of International Law.

Anwar, K., \& Darwis, D. (2015). Formulasi kebijakan pendidikan gratis kabupaten Pelalawan tahun 2013. Jom FISIP, 2(2).

Arif, M.I.A.M., Rahman, N.H.A., \& Hanapi, H. (2017). Madrasah Education System And Terrorism: Reality And Misconception. International Journal of Educational Best Practices, 1(1), 83-92.

Asrori, A. (2019). Radikalisme di indonesia: Antara Historisitas dan Antropisitas. Jurnal Studi Keislaman, 9(2).

Bintari, A., \& Pandiangan, L.H.S. (2016). Formulasi Kebijakan Pemerintah Tentang Pembentukan Badan Usaha Milik Daerah (Bumd) Perseroan Terbatas (Pt) Mass Rapid Transit (Mrt) Jakarta Di Provinsi Dki Jakarta. Cosmogov. Jurnal Ilmu Pemerintahan ISSN, 2442, 5958.

Bradford, E., \& Wilson, M. A. (2013). When terrorists target schools: An exploratory analysis of attacks on educational institutions. Journal of police and criminal psychology, 28(2), 127-138.

Edyar, B. (2017). Religious Radicalism, Jihad And Terrorism. AJIS : Academic Journal of Islamic Studies. vol. 2, no. 1.

Haryono, E. (2010). Kebijakan Anti-Terorisme Indonesia: Dilema Demokrasi dan Represi, JSP: Jurnal Ilmu Sosial dan Ilmu Politik. Vol 14, Nomor 2, November ISSN 1410-4946.

https://www.medcom.id/pendidikan/news-pendidikan/aNrazx1K-kemenag-revisikurikulum-pai-dan-bahasa-arab-untuk-madrasah (Diakses pada tanggal 29 April 2021 Pukul 13. 50 Wib)

https://www.muslimahvoice.com/2019/12/apa-di-balik-polemik-materi-khilafah.html Apa di Balik Polemik Materi Khilafah dan Jihad di Kurikulum Madrasah? (Diakses pada tanggal 28 April 201 Pukul 13. 20 Wib). 
http://www.start.umd.edu/gtd/. Global Terrorism Database1, terrorist groups killed roughly 43,412 people (diakses pada tanggal 29 April 2021.

Khan, L.A. (2005). The Essentialist Terrorist. Washburn Law Journal Fall.

Miles, M.B., \& Huberman, M.A. (2014). Qualitative Data Analysis. California: Sage Publishing.

Muadi, S., Ismail, M.H., \& Sofwani, A. (2016). Konsep Dan Kajian Teori Perumusan Kebijakan Publik. Jurnal Review Politik, 6(2).

Muhadjir, N. (1996). Metodologi Penelitian Kualitatif. Yogyakarta: Bayu Indra Grafika

Prasetyo, B. (2019). Pembubaran Hizbut Tahrir di Indonesia dalam Perspektif Sosial Politik. Analisis: Jurnal Studi Keislaman. Volume 19, No. 2, Tahun 2019

Rohman \& Nurhasanah. (2019). Radicalism Based On Religious Perspective. Journal of Terrorism Studies, Volume 1, No. 1 ISSN : 2656-9965, May 2019.

Surat Edaran B-4339.4/DJ.I/Dt.I.I/PP.00/12/2019 pada tanggal 4 Desember 2019.

SK Dirjen Pendidikan Islam Nomor 3751, Nomor 5162 dan Nomor 5161 Tahun 2018 tentang Juknis Penilaian Hasil Belajar pada MA, MTs, dan MI.

START ( Study of Terrorism and Responses to Terrorism). "Data Collection Methodology." Available at http:/ / www.start.umd.edu/gtd/using-gtd/ (accessed 28 April 2021).

Syauqillah, M., \& Faton, M.A. (2019). The Transmission of Global and Regional Extremism in Indonesia. Journal of Terrorism Studies, 1(1), 1.

Tahaj, R.A., \& Logahan, J.M. (2019). Counter Radicalization Analysis in Efforts to Prevent the Spread of Radical Ideology in Indonesia. Journal of Terrorism Studies, 1(1), 3.

Tilaar, H.A.R., \& Nugroho, R. (2008). Kebijakan Pendidikan (1st ed.). Pustaka Pelajar.

Tilaar, H.A.R., \& Nugroho, R. (2012). Kebijakan Pendidikan: Pengantar untuk Memahami Kebijakan Pendidikan Sebagai Kebijakan Publik, (Yogyakarta: Pustaka Pelajar.

Winarno, B. (2012). Kebijakan Publik, Teori, Proses, dan Studi Kasus. Yogyakarta: CAPS. 